\title{
Culture and storage of pig embryos
}

\author{
D. L. Davis \\ Department of Animal Sciences and Industry, Kansas State University, Manhattan, Kansas 66506, U.S.A.
}

\begin{abstract}
Summary. Studies have consistently demonstrated that 4-cell pig embryos can be cultured to the blastocyst stage in a simple salt solution containing bovine serum albumin (BSA). Pig embryos appear to be detrimentally affected by lower levels of lactate and pyruvate than are mouse embryos, but in general their in-vitro requirements are similar. Results from embryos cultured between the 4-cell and blastocyst stages are consistent enough to allow the use of culture for the storage and shipment of pig embryos. However, results obtained after culture and transfer indicate a reduction in viability similar to that observed for cultured cattle and mice embryos.

Embryos collected earlier than the 4-cell stage have been difficult to support in vitro beyond one or two cleavage divisions. Pig blastocysts may benefit from serum in their in-vitro environment: lamb, fetal calf and human serum supported continued development but pig serum was detrimental. There are conflicting reports on the efficacy of a more complete medium (Minimum Essential Medium) on the growth of pig embryos.

Embryo culture will almost certainly contribute to the application of biotechnology to embryos by providing more appropriate environments for in-vitro manipulations and also, possibly, by providing a system for the early selection of desirable embryonic genotypes.
\end{abstract}

\section{Introduction}

Studies of the in-vitro development of embryos from the domestic species are usually looked upon as supporting embryo transfer or the gene and cell manipulation techniques which have come to the forefront recently. However, the study of embryo culture is equally important in contributing to the understanding of the physiology of embryos in early pregnancy. Development of more effective embryo culture procedures based on a more complete understanding of embryonic physiology would benefit embryo transfer and related technologies and also advance efforts to understand the mechanisms operating in the very earliest stages of pregnancy. This review will emphasize both the physiology of early embryos and their in-vitro requirements, since improved understanding of these stages could form the basis for developing culture techniques to support pig embryos in vitro more in the manner to which they are accustomed in vivo.

\section{Culture of cleavage-stage pig embryos}

\section{Results obtained after transfer of cultured embryos}

The efficacy of current embryo culture procedures can be quickly appreciated by examining the ability of cultured embryos to develop to term after transfer to surrogate mothers. The largest relevant source of data comes from embryo transfers performed for commercial purposes and for which embryos have been maintained in vitro for up to $27 \mathrm{~h}$ between recovery and transfer. Although $40-50 \%$ of embryos transferred are represented by pigs born when transfers are 
performed shortly after collection, only about $26 \%$ develop to term after in-vitro storage for 20-27 h (James et al., 1980) or 4-10 h (James, James, Martin, Reed \& Davis, 1983). Although it could be argued that this is due to less than ideal conditions during 'field application' of embryo culture, a similar loss in viability accompanies mouse embryo culture under carefully controlled conditions. Massip, van der Zwalmen, Puissant, Camus \& Leroy (1984) reported that the number of transferred embryos represented by live fetuses on Day 15 of pregnancy declined from $50.7 \%$ for mouse blastocysts developing in vivo to $29.8 \%$ for blastocysts developed in vitro. The stage when cultured embryos are lost has not been studied for the pig but Day-10 to -12 cow blastocysts, cultured for $24 \mathrm{~h}$, experience heavier losses than do uncultured blastocysts between Days 28 and 35 of pregnancy (Renard, Heyman \& Ozil, 1980) and Massip et al. (1984) reported that mouse blastocysts grown in vitro had an increased incidence of resorbing implantation sites on Day 15 of pregnancy. Perhaps this explains why estimates of the survival of cultured and transferred pig embryos obtained on Days 20-33 of pregnancy (Pope \& Day, 1977; Davis \& Day, 1978) are higher than for studies measuring development to term (James et al., 1980, 1983).

The detrimental effect of culture on embryo viability, even though morphologically normal development is achieved, illustrates the need for measures of embryo viability in addition to morphological evaluations.

\section{Effect of morphological stage on culture results}

Figure 1 depicts the morphological stages timed from onset of oestrus (Day 0 ) and is consistent with the data of Hunter (1974) and Oxenreider \& Day (1965). Changes in the susceptibility of pig embryos to culture are correlated with morphological and ultrastructural aspects of embryonic development but the physiological basis for this apparent correlation remains to be established. A 'block' which is difficult to overcome in vitro has been reported for the pig (4-cell stage: Polge \& Frederick, 1968; Rundell \& Vincent, 1968), mouse (2-cell stage for most lines: Whitten \& Biggers, 1968), rat (8-cells: Folstad, Bennett \& Dorfman, 1969; Mayer \& Fritz, 1974), hamster (8-cells: Whittingham \& Bavister, 1974) and cow (8-cells: Renard, du Mesnil du Buisson, Wintenberger-Torres \& Menezo, 1976). In some of these species there are reports of successful culture of earlier embryos through these block stages but they involve the use of embryos from only certain inbred lines or their crosses in the case of mouse embryos (Whitten \& Biggers, 1968) or the use of serum in the case of cattle embryos (Wright, Anderson, Cupps \& Drost, 1976) and high levels of bovine serum albumin for pig embryos (Menino \& Wright, 1982). Despite these notable successes there are difficulties in culturing the earliest cleavage stages to blastocysts in the species listed.

Pope's (1972) observations on pigs are illustrative. In Brinster's Medium for Ovum Culture-2, supplemented with $1 \mathrm{mg}$ glucose/ml, $18 \%$ of $276 \mathrm{l}$ - to 4-cell embryos formed blastocysts. In a second experiment only $2 \cdot 6 \%$ of 663 embryos reached the blastocyst stage. Inconsistencies in culture results within the same laboratory for the early cleavage stages are not limited to the pig. Kane (1983) demonstrated that different lots of BSA differ in their ability to support cell multiplication and hatching of rabbit blastocysts. This is particularly pertinent when it is realized that cleavage-stage embryos from only a few species can be supported in vitro and then only in media containing BSA or serum (reviews by Kane, 1978; Brackett, 1981). The need for BSA is less stringent for mouse embryos since development from the 2-cell to blastocyst stage in BSA-free medium was reported by Cholewa \& Whitten (1970). However, no more than a single cleavage could be consistently obtained for 1-cell zygotes unless BSA was included in the medium. Kane (1985) has presented evidence that commercial BSA preparations contain an embryonic growth factor and suggests that the stimulation of blastocyst growth by high levels of BSA, which has been reported for mouse, pig and sheep embryos (see Kane, 1985, for references), may be attributable to this factor. In this regard it may be relevant that Menino \& Wright (1982) were successful in cultivating 1 -cell pig embryos to the blastocyst stage using Whitten's medium containing $1.5 \%$ 


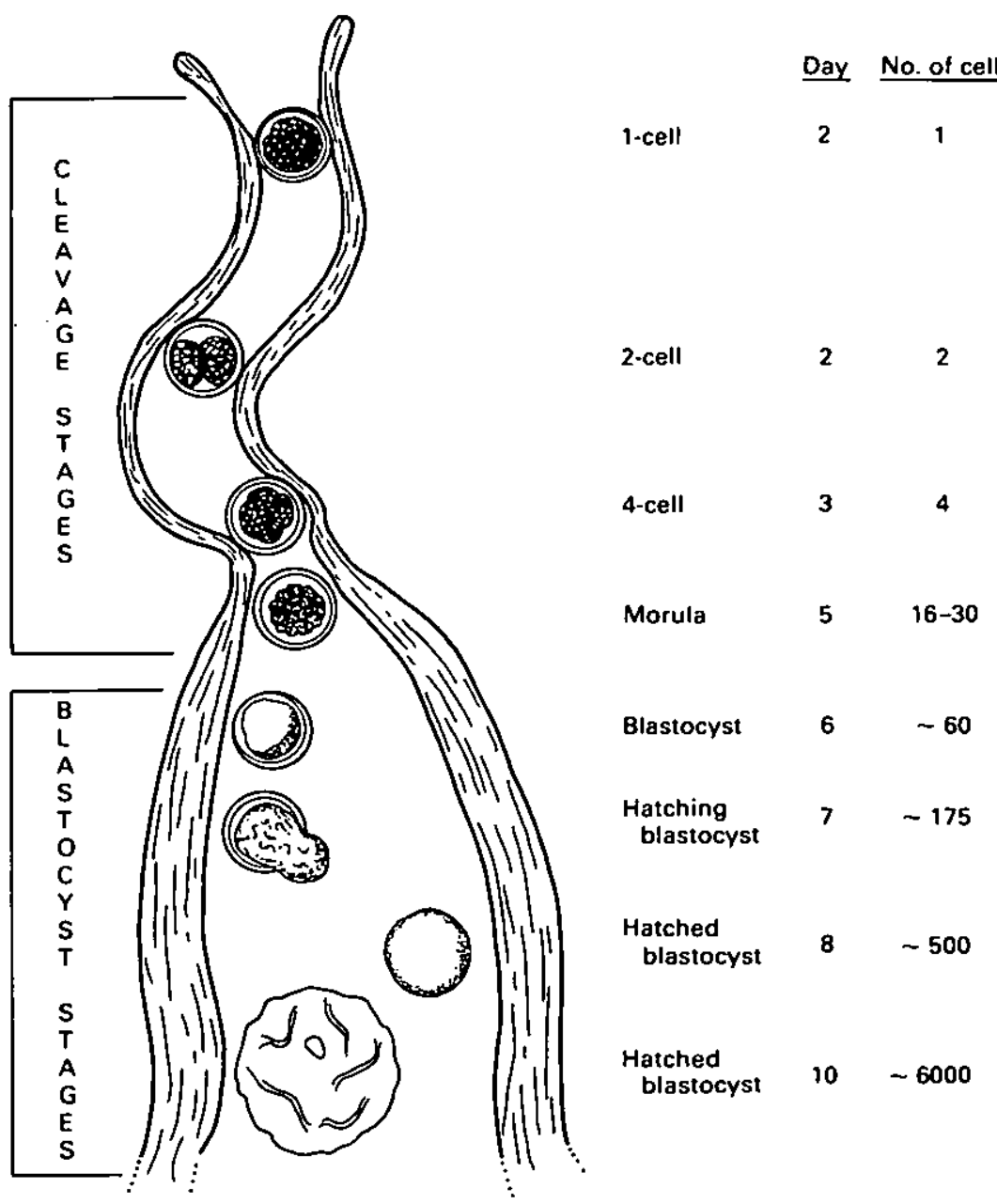

Fig. 1. Cleavage and blastocyst stages for pig embryos. Based on data from Oxenreider \& Day (1965) and Hunter (1974). Cell number was estimated using nuclei counts (Robl, 1979).

BSA. Other embryo-supporting properties attributed to BSA include the chelation of toxic ions (Whitten, 1971; Whittingham, 1972), the conveyance of physical properties to the medium (Brinster, 1965a) and the provision of fatty acids and other molecules which could serve as energy sources (Kane, 1979). Perhaps a completely defined medium which would support early cleavage stages is attainable. If so the vagaries introduced by BSA supplementation could be eliminated.

True nucleoli first appear in the nuclei of pig embryos at about the 8-cell stage (Norberg, 1973) which may indicate important events during the critical 4-cell stage. The 4-cell stage is especially long in the pig (Hunter, 1974; Polge, 1982) and J. C. Osborn \& C. Polge (cited by Polge, 1982) observed that a number of new proteins were synthesized during the 4-cell stage. They suggest that deficiencies in the synthesis of these new proteins may occur during in-vitro development.

Does the maternal environment modify development of cleavage-stage embryos?

The ease with which the development of embryos of certain species can be supported in media containing only inorganic salts and BSA may indicate that the mother provides nothing more than 
a suitable incubator during the cleavage and early blastocyst stages. However, Kane (1978) has suggested that embryos from some species may require an 'hormonal trigger' during cleavage to overcome the block encountered in vitro. Perhaps the oviduct and/or uterus are producing growth factors analogous to that in the formic-acid extract of BSA (Kane, 1985). Such a situation could explain that mouse embryos develop more slowly in vitro than in vivo (Bowman \& McLaren, 1970) and is consistent with reports by Wilmut \& Sales (1981) and Lawson, Parr \& Cahill (1983) which show that development of 16-cell and blastocyst-stage sheep embryos is modified in accordance with the uterine environment of an asynchronous recipient. However, if there is an hormonal stimulus provided in vivo it may be a molecule of wide distribution since the rabbit oviduct promotes normal development of l-cell pig embryos (Polge, Adams \& Baker, 1972).

\section{Amino acids and vitamins}

Four-cell pig embryos readily develop to blastocysts in simple salt solutions containing BSA but without the addition of free amino acids or vitamins (Wright \& Bondioli, 1981). This is similar to the situation for mouse embryos (Brinster, 1965a) but contrasts with rabbit embryo culture results since amino acids and vitamins, in addition to BSA, are important constituents of media supporting blastocyst formation by rabbit embryos in vitro (Kane \& Foote, 1970).

\section{Energy sources}

It is possible to culture 4-cell pig embryos to blastocysts in media containing $0 \cdot 1 \%$ or $0.4 \% \mathrm{BSA}$ but no glucose or other energy source (Graves, Dickey \& McConnell, 1977; Davis \& Day, 1978). This may indicate that pig embryos are able to rely on endogenous energy stores during cleavage, or that fatty acids bound to BSA are serving as energy sources. Brinster \& Thomson (1966) observed that 8-cell mouse embryos could develop to blastocysts in a simple inorganic salt solution if BSA or any of several amino acids were added.

Investigations of the response of pig embryos to lactate and pyruvate, which serve important roles in mouse embryo culture (Brinster, 1965b), produced unexpected detrimental effects. Not only are lactate and pyruvate not required by 4-cell pig embryos but, at the levels used for mouse

Table 1. Effect of lactate and pyruvate on early cleavage stage pig embryos cultured for 4 days (unpublished data)

\begin{tabular}{|c|c|c|c|c|}
\hline \multirow[b]{2}{*}{ Treatment } & \multicolumn{2}{|c|}{ Embryos } & \multirow[b]{2}{*}{$\begin{array}{l}\text { No. } \\
\text { stained }\end{array}$} & \multirow[b]{2}{*}{$\begin{array}{l}\text { Nuclei/embryo } \\
\text { (mean } \pm \text { s.e.m.) }\end{array}$} \\
\hline & Cultured & $\begin{array}{c}\text { Forming } \\
\text { blastocysts (\%) }\end{array}$ & & \\
\hline \multicolumn{5}{|l|}{ Experiment I } \\
\hline MKRB十 & 17 & $17(100)$ & 14 & $72 \cdot 0 \pm 6.6$ \\
\hline MKRB +0.025 mM-pyruvate & 17 & $17(100)$ & 17 & $77.5 \pm 7.1$ \\
\hline MKRB + $0.125 \mathrm{~mm}$-pyruvate & 15 & $14(93)$ & 10 & $76.4 \pm 13.5$ \\
\hline MKRB +0.25 mm-pyruvate & 15 & $14(93)$ & 14 & $65 \cdot 3 \pm 6 \cdot 3$ \\
\hline \multicolumn{5}{|l|}{ Experiment $/ 1$} \\
\hline MKRB & 18 & $7(39)$ & 13 & $68 \cdot 2 \pm 10 \cdot 3$ \\
\hline MKRB +0.25 mM-pyruvate & 22 & $8(36)$ & 12 & $38.1 \pm 6.8$ \\
\hline $\begin{array}{l}\text { MKRB +0.25 mM-pyruvate } \\
+25 \text { mM-lactate }\end{array}$ & 23 & $3(13)^{*}$ & 9 & $38 \cdot 2 \pm 11 \cdot 5$ \\
\hline
\end{tabular}

MKRB = Modified Krebs-Ringer bicarbonate medium (Davis \& Day, 1978) including bovine serum albumin $(4 \mathrm{mg} / \mathrm{ml})$ and glucose $(1 \mathrm{mg} / \mathrm{ml})$.

+ Four- 10 8-cell embryos at recovery.

$\ddagger$ Three- to 4-cell embryos at recovery.

- Significantly different from other values $\left(P<0 \cdot 10 ; \chi^{2}=4 \cdot 85,2\right.$ d.f. $)$. 
embryos, they inhibited development to blastocysts (Davis \& Day, 1978) or blastocyst expansion (Stone, Quinn \& Seamark, 1984). Brinster (1965b), however, reported that 4-cell mouse embryos could rely on glucose as an energy source: therefore only the first two cleavage divisions in the mouse require pyruvate or a closely related metabolite and lack of a requirement for these substrates by 4-cell pig embryos does not necessarily indicate species differences in the type of energy source required. Kane (1976) found that l-cell rabbit embryos will develop in a simple salt solution containing defatted BSA if pyruvate or any of five long-chain fatty acids are provided and to some extent acetic and propionic acid could support development. The effects of fatty acids on pig embryos have not been studied.

There are apparently unidentified factors affecting the response of pig embryos to lactate and pyruvate. Davis \& Day (1978) reported that these substrates interfered with development to blastocysts. Stone et al. (1984) observed no effects on blastocyst formation but the percentage of embryos hatching and expanding larger than the zona from which they escaped was decreased. Work at Kansas State University (J. M. Robl \& D. L. Davis, unpublished) has demonstrated no detrimental effects of pyruvate $(0.025-0.25 \mathrm{~mm})$ but the combination of lactate $(25 \mathrm{~mm})$ and pyruvate $(0.025 \mathrm{~mm})$ was inhibitory (Table 1). These studies are consistent in demonstrating detrimental effects of lactate and pyruvate on pig embryos but the details of the response differ slightly in each report. Perhaps embryo genotypes, or other as yet unidentified factors, are modifying the results from different locations.

\section{Inorganic salts, buffers and oxygen levels}

Similarly, the osmolarity and $\mathrm{pH}$ used for pig embryo culture have been derived from mouse embryo experiments. Bicarbonate (reviewed by Wright \& Bondioli, 1981) and phosphate (Kruff, Szilvassy \& Tenhumberg, 1984; Polge, 1982) buffers have been used successfully for the culture of 4-cell and morula-stage pig embryos. Phosphate-buffered medium was supplemented with lamb serum which would provide bicarbonate ions if this is an important carbon source for pig embryos. In-vitro development of mouse embryos is quite limited unless bicarbonate is included in the medium (Quinn \& Wales, 1973) and although 1-cell rabbit eggs will develop to morulae in the absence of bicarbonate in a Hepes-buffered medium they require a small amount of $\mathrm{HCO}_{3}$ to develop to blastocysts (Kane, 1975).

Wright (1977) reported that the reduced oxygen atmosphere $\left(5 \% \mathrm{O}_{2}, 5 \% \mathrm{CO}_{2}, 90 \% \mathrm{~N}_{2}\right)$ found to be preferred by sheep and cattle embryos in vitro (Tervit, Whittingham \& Rowson, 1972) also produced superior cleavage rates for pig embryos when compared to the more commonly used $5 \%$ $\mathrm{CO}_{2}, 95 \%$ air atmosphere.

\section{Culture of pig blastocysts}

Cleavage-stage pig embryos develop to blastocysts in simple salt solutions containing BSA as the only macromolecule (Pope, 1972; Schneider, Krug \& Olds, 1975; Wright, 1977; Davis \& Day, 1978). However, cell division and growth stop soon after cavitation and only a few blastocysts hatch from the zona pellucida. Pig embryos first benefit from the addition of serum to their culture medium at the late morula to early blastocyst stage (Robl \& Davis, 1981) which is similar to observations with mouse embryos (Hsu, Baskar, Stevens \& Rash, 1974; McLaren \& Hensleigh, 1975). However, the species providing the serum affects results since pig serum is detrimental (Robl \& Davis, 1981; Kruff et al., 1984; Stone et al., 1984), fetal calf and lamb serum are growth promoting and approximately equivalent (Robl \& Davis, 1981) and human serum is superior to fetal calf serum (Stone et al., 1984). Serum provides amino acids and a necessary macromolecular fraction for mouse blastocysts (Gwatkin, 1966; Spindle \& Pedersen, 1973) and similar roles are likely for pig blastocysts which are just entering a phase of rapid growth and differentiation (Heuser \& Streeter, 1929). Perhaps this is why dialysed fetal calf serum retains its ability to support hatching and 
blastocyst expansion by pig embryos but the resulting blastocysts contain fewer cells than do blastocysts grown in nondialysed serum (Meyen \& Davis, 1983). Although all culture systems supporting growth of pig blastocysts have used serum, many types of studies would benefit if blastocysts could be supported in serum-free media. Such a medium has been developed for mouse blastocysts (Rizzino \& Sherman, 1979), and it is therefore possible that a serum-free medium can be developed for pig blastocysts.

Stone et al. (1984) found that Minimum Essential Medium (MEM) was superior to mKRB in supporting hatching and blastocyst expansion by pig embryos. MEM contains amino acids and vitamins in addition to the inorganic salts, glucose and BSA in mKRB. It seems reasonable that pig blastocysts would benefit from such additional nutrients, but our results (Meyen \& Davis, 1983) have consistently shown a detrimental effect when MEM amino acids and vitamins are added to mKRB. Reasons for this discrepancy are not apparent but may involve variations in culture procedures or in the genotypes of the embryos. Wright, Watson \& Chaykin (1978) found that embryos collected from different strains of mice differed in their response to BSA concentration and the number of embryos per microdrop, as measured by hatching rate. Perhaps conflicting results between laboratories culturing pig blastocysts could, in part, be explained by genetic effects.

Mouse embryos developing in vivo implant soon after hatching and when grown in vitro they attach to the dish or other surface and the trophoblast proliferates in a monolayer (see McLaren \& Hensleigh, 1975). Since pig embryos do not attach to the uterus for several days after hatching, and do not invade the maternal tissues, it might be expected that their behaviour in vitro would differ from that of mouse embryos. However, Shaffer \& Wright (1978) and Kuzan \& Wright (1982) observed that pig blastocysts attached and grew in a manner similar to that of mouse blastocysts. No other investigators have indicated a tendency for pig blastocysts to attach to culture vessels but this may again reflect differences in culture procedures since in the above two reports pig embryos were cultured under conditions which have been shown to promote attachment and trophoblast outgrowth by mouse blastocysts. In vitro, therefore, the behaviour of hatched blastocysts may be similar for embryos from species varying widely in their type of placentation. This may be consistent with the concepts put forth by Samuel (1971), Samuel \& Perry (1972) and Mullins, Bazer \& Roberts (1980) which suggest that the pig trophoblast has invasive abilities similar to those of the mouse but that the pig uterus normally holds their invasive potential in check.

Although our ability to support pig blastocyst growth and development in vitro is fairly limited at present, improvements in this area would provide exciting new avenues for research addressing not only the requirements of the blastocysts, but also studies of the mechanisms involved in establishing pregnancy. Investigators culturing embryos of the domestic species often look to results with mouse and rabbit embryos to provide hypotheses to be tested with their scarcer supplies of embryos. However, the advanced embryonic stages of the domestic ungulates are supported by large chorionic vesicles (Wimsatt, 1975) and provide many advantages for the study of mechanisms involved in establishing pregnancy, including their relatively large size and the ease with which embryonic and maternal tissues can be separated. As a consequence, studies with farm animal embryos have made a major contribution to the investigation of the paracrine/endocrine role of the conceptus. The pig is uniquely suited for these investigations by the virtue of a large chorionic vesicle (Heuser \& Streeter, 1929) and the production of 10-20 embryos without the need for superovulation. Several investigators have used short-term cultures to study the production of steroids, prostaglandins, and other biologically important molecules (see Godkin, Bazer, Lewis, Geisert \& Roberts, 1982; Flint, Heap, Saunders, Wise \& Ziecek, 1980; Powell-Jones, Lester, Polge \& Hartree, 1984). However, essentially nothing is known of the in-vitro requirements of these embryos and although many biosynthetic pathways continue to function in vitro it seems unlikely that normal embryonic development is obtained with present incubation methods. Whilst this does not diminish the usefulness of the findings of these experiments, the availability of culture techniques that supported approximately normal morphogenesis would permit the investigation in vitro of other fascinating and biologically important phenomena such as blastocyst elongation. 


\section{Regulation of embryonic development during cleavage and cavitation}

Regulation of the development of early embryos may be genetically programmed or modified by hormones or other molecules. Evidence has accumulated which verifies the ability of the early embryo to control its own fate through the generation of chemical messages and the ability of pig blastocysts (or chorionic vesicles) to synthesize oestrogens is well established (see Heap, Flint \& Staples, 1983). However, experiments using specific steroid inhibitors or antagonists and in-vitro culture have produced evidence of the synthesis of oestrogen by cleavage-stage mouse embryos, and also a requirement for oestrogen in normal embryonic development (Sengupta, Roy \& Manchanda, 1982) and of oestrogen effects on rabbit blastocyst development and metabolism (Paria, Sengupta \& Manchanda, 1984). Other experiments have produced evidence of similar roles for histamine and polyamines synthesized by cleaving embryos (Dey \& Johnson, 1980; Hudgins, Mukerjee \& Dey, 1982; Alexandre, 1979) and for prostaglandins for in-vitro hatching by mouse blastocysts (Biggers, Leonov, Baskar \& Fried, 1978; Hurst \& MacFarlane, 1981). We have recently found that inhibiting histamine (Lane \& Davis, 1982) or spermidine and spermine (Lane \& Davis, 1984) synthesis with specific enzyme inhibitors interrupted cleavage in pig embryos and prevented blastocyst formation; because the effects of both inhibitors could be reversed, their action appeared not to be related to nonspecific cytotoxic effects.

The addition of steroid hormones to embryo culture media has produced conflicting results (for references see Warner \& Tollefson, 1978). There is no evidence that either progesterone or oestradiol modulates RNA synthesis by 8 -cell or blastocyst-stage mouse embryos (Warner \& Tollefson, 1977, 1978) but these authors suggest that steroid hormones could be affecting embryos by acting on embryonic membranes to affect cleavage and permeability. Niemann \& Elsaesser (1984) have reported that Day-6 pig blastocysts specifically bound oestradiol, but not progesterone, suggesting a function for oestrogen in early embryonic development. Bowman \& McLaren (1970) observed that the addition of oestradiol to the culture medium for mouse embryos increased blastocyst diameter but had no effect on cell numbers. These observations, coupled with the reports cited above, leave open the possibility that exogenous hormones could alter the development of cleavage and early blastocyst embryos.

\section{Biotechnology and pig embryo culture}

One application of embryo culture is in procedures for the manipulation of the genes or cells of embryos (reviewed by Robl \& First, 1985). However, agronomists are now also contemplating the use of plant cell cultures to select agronomically useful mutants (Chaleff, 1983). When combined with other technologies, such as embryo splitting, the identification of embryos with desirable traits might substantially shorten the generation interval and speed genetic progress. Current knowledge does not permit free speculation as to the use of this approach but one possible example could be direct selection for the 'heat shock gene' as described for rabbits by Heikkila \& Schultz (1984). These workers were able to enhance transcription of a gene coding for a protein of molecular weight of 70000 believed to be similar to a heat-shock protein found in other eukaryotic systems (for reviews see Ashburner \& Bonner, 1979; Tanquay, 1983). The induction of these stress proteins has been correlated with a dramatic increase in the ability to withstand thermal stress in yeast (McAlister \& Finkelstein, 1980), Dictyostelium (Loomis \& Wheeler, 1980) and Chinese hamster fibroblasts ( $\mathrm{Li} \& \mathrm{Werb}, 1982$ ). This protein is also produced in response to chemical and mechanical injury (Heikkila \& Schultz, 1984) and may therefore be of physiological importance to the embryos or offspring produced. Direct measurement of the heat-shock protein may not be feasible, but perhaps selection of embryos surviving thermal or other in-vitro stresses might be successful. In fact, one might speculate that embryos surviving current culture and transfer procedures are a genetically distinct population. 
I thank T. Paph for typing the manuscript. Published as contribution No. 85-449-J from the Kansas Agricultural Experiment Station.

\section{References}

Alexandre, H. (1979) The utilization of an inhibitor of spermine and spermidine synthesis as a tool for the study of the determination of cavitation in the preimplantation mouse embryo. J. Embryol. exp. Morph. $53,145-162$.

Ashburner, M. \& Bonner, J.J. (1979) The induction of gene activity in Drosophila by heat shock. Cell 17, 241-254.

Biggers, J.D., Leonov, B.V., Baskar, J.F. \& Fried, J. (1978) Inhibition of hatching of mouse blastocysts in vitro by prostaglandin antagonists. Biol. Reprod. 19. 519-533.

Bowman, P. \& McLaren, A. (1970) Cleavage rate of mouse embryos in vivo and in vitro. J. Embryol. exp. Morph. 24, 203-207.

Brackett, B.G. (1981) In vitro culture of the zygote and embryo. In Fertilization and Embryonic Development in Vitro, pp. 61-79. Eds L. Mastroianni, Jr \& J. D. Biggers. Plenum Press, New York.

Brinster, R.L. (1965a) Studies on the development of mouse embryos in vitro: Ill. The effect of fixed nitrogen source. J. exp. Zool. 158, 69-78.

Brinster, R.L. (1965b) Studies on the development of mouse embryos in virro. V. Interaction of energy sources. J. Reprod. Ferı. 10, 227-240.

Brinster, R.L. \& Thomson, J.L. (1966) Development of eight-cell mouse embryos in vitro. Expl Cell Res. 42, 308-315.

Chaleff, R.S. (1983) Isolation of agronomically useful mutants from plant cell cultures. Science, N.Y. 219, 676-682.

Cholewa, J.A. \& Whitten, W.K. (1970) Development of two-cell mouse embryos in the absence of a fixednitrogen source. J. Reprod. Fert. 22, 553-555.

Davis, D.L. \& Day, B.N. (1978) Cleavage and blastocyst formation by pig eggs in vitro. J. Anim. Sci. 46, 1043-1053.

Dey, S.K. \& Johnson, D.C. (1980) Histamine formation by mouse preimplantation embryos. J. Reprod. Fers. 60, 457-460.

Flint, A.P.F., Heap, R.B., Saunders, P.T.K., Wise, T.H. \& Ziecek, A.J. (1980) Hormone production by the preimplantation pig blastocyst. Proc. $9 \mathrm{th} / \mathrm{mt}$. Congr. Anim. Reprod. \& A.I., Madrid, pp. 201-208.

Folstad, L., Bennett, J.P. \& Dorfman, R.I. (1969) In vitro culture of rat ova. J. Reprod. Fert. 18, 145-146.

Godkin, J.D., Bazer, F.W., Lewis, G.S., Geisert, R.D. \& Roberts, R.M. (1982) Synthesis and release of polypeptides by pig conceptuses during the period of blastocyst elongation and attachment. Biol. Reprod. 27, 977-987.

Graves, W.M., Dickey, J.F. \& McConnell, J.C. (1977) $l n$ vitro development of porcine embryos. Proc. $69 \mathrm{th}$ Ann. Mig Am. Soc. Anim. Sci., Madison, p. 164, Abstr.

Gwatkin, R.B.L. (1966) Amino acid requirements for attachment and outgrowth of the mouse blastocyst in vitro. J. Cell Physiol. 68, 335-344.
Heap, R.B., Flint, A.P.F. \& Staples, L.D. (1983) Endocrinology of trophoblast in farm animals. In Biology of the Blastocyst, pp. 353-400. Eds Y. W. Loke \& A. Whyte. Elsevier, New York.

Heikkila, J.J. \& Schultz, G.A. (1984) Different environmental stresses can activate the expression of a heat shock gene in rabbit blastocysts. Gamere Res. $10,45-56$.

Heuser, C.H. \& Streeter, G.L. (1929) Early stages in the development of pig embryos, from the period of initial cleavage to the lime of appearance of limb-buds. Contr. Embryol. Carnegie Instn 20, 1-29.

Hsu, Y.-C., Baskar, J., Stevens, L.C. \& Rash, J.E. (1974) Development in vitro of mouse embryos from the two-cell to the early somite stage. J. Embryol. exp. Morph. 31, 235-245.

Hudgins, L., Mukerjee, S. \& Dey, S.K. (1982) Pre-implantation embryo development in the mouse-role of histidine decarboxylase. Gamete Res. 6, 121-125.

Hunter, R.H.F. (1974) Chronological and cytological details of fertilization and early embryonic development in the domestic pig, Sus scrofa. Anat. Rec. 178, 169-185.

Hurst, P.R. \& MacFarlane, D.W. (1981) Further effects of non steroidal anti-inflammatory compounds on blastocyst hatching in vitro and implantation rates in the mouse. Biol. Reprod. 25, 777-784.

James, J.E., Reeser, P.D., Davis, D.L., Straiton, E.C., Talbot, A.C. \& Polge, C. (1980) Culture and long-distance shipment of swine embryos. Theriogenology 14, $463-469$.

James, J.E., James, D.M., Martin, P.A., Reed, D.E. \& Davis, D.L. (1983) Embryo transfer for conserving valuable genetic material from swine herds infected with pscudorabies. J. Am. vet. med. Ass. 183, 525-528.

Kane, M.T. (1975) Bicarbonate requirements for culture of one-cell rabbit ova to blastocysts. Biol. Reprod. 12 , $552-555$.

Kane, M.T. (1976) Growth of fertilized one-cell rabbit ova to viable morulae in the presence of pyruvate or fatty acids. J. Physiol., Lond. 263, 235-236P.

Kane, M.T. (1978) Culture of mammalian ova. In Control of Reproduction in the Cow, pp. 383-387. Ed. J. M. Sreenan. Martinus Nijhoff, The Hague.

Kane, M.T. (1979) Fatty acids as energy sources for culture of one-cell rabbit ova to viable morulae. Biol. Reprod. 20, 323-332.

Kane, M.T. (1983) Variability in different lots of commercial bovine serum albumin affects cell multiplication and hatching of rabbit blastocysts in culture. $J$. Reprod. Fert. 69, 555-558.

Kane, M.T. (1985) A low molecular weight extract of bovine serum albumin stimulates rabbit blastocyst cell division and expansion in virro. J. Reprod. Fert. 73, 147-150.

Kane, M.T. \& Foote, R.H. (1970) Culture of two- and four-cell rabbit embryos to the expanding blastocyst 
stage in synthetic media. Proc. Soc, exp. Biol. Med. $133,921-925$.

Kruff, B., Szilvassy, B. \& Tenhumberg, H. (1984) Experiences with culture of porcine embryos. Proc. IOth Int. Congr. Anim. Reprod. \& A.I., Urbana-Champaign, 2, 233, Abstr.

Kuzan, F.B. \& Wright, R.W., Jr (1982) Blastocyst expansion, hatching, and attachment of porcine embryos cocultured with bovine fibroblasts in vitro. Anim. Reprod. Sci. 5, 57-63.

Lane, S.M. \& Davis, D.L. (1982) Evidence for a role for embryonic histamine synthesis in swine blastocyst formation. J. Anim. Sci. Suppl. 1, 364-365, Abstr.

Lane, S.M. \& Davis, D.L. (1984) Regulation of embryo development in pigs: effect of inhibiting polyaminc synthesis. J. Anim. Sci. 59 (Suppl. 1), 122-123, Abstr.

Lawson, R.A.S., Parr, R.A. \& Cahill, L.P. (1983) Evidence for maternal control of blastocyst growth after asynchronous transfer of embryos to the uterus of the ewe. J. Reprod. Fert. 67, 477-483.

Li, C.C. \& Werb, Z. (1982) Correlation between synthesis of heat shock proteins and development of thermololerance in Chinese hamster fibroblasts. Proc. natn. Acad. Sci. U.S.A. 79, 3268-3272.

Loomis, W.F. \& Wheeler, S.A. (1980) Heat shock response of Dictyostelium. Dev/ Biol. 79, 399-408.

Massip, A., Van der Zwalmen, P., Puissant, F., Camus, M. \& Leroy, F. (1984) Effects of in vitro fertilization, culture, freezing and transfer on the ability of mouse embryos to implant and survive. J. Reprod. Fert. 71, 199-204.

Mayer, J.F., Jr \& Fritz, H.I. (1974) Culture of preimplantation rat embryos and the production of allophenic rats. J. Reprod. Fert. 39, 1-9.

McAlister, L. \& Finkelstein, D.B. (1980) Heat shock proteins and thermal resistance in yeast. Biochem. Biophys. Res. Commun. 93, 819-824.

McLaren, A. \& Hensleigh, H.C. (1975) Culture of mammalian embryos over the implantation period. In The Early Development of Mammals, pp. 45-60. Ed. A. E. Wild. Cambridge University Press.

Menino, A.R. \& Wright, R.W., Jr (1982) Development of one-cell porcine embryos in two culture systems. $J$. Anim. Sci. 54, 583-587.

Meyen, B.A. \& Davis, D.L. (1983) Effects of medium and serum on swine embryos. J. Anim. Sci. 57 (Suppl. 1), 359, Abstr.

Mullins, D.E., Bazer, F.W. \& Roberts, R.M. (1980) Secretion of a progesterone-induced inhibitor of phasminogen activator by the porcine uterus. Cell 20, 865-872.

Niemann, H. \& Elsaesser, F. (1984) Uptake and effects of ovarian steroids in the early pig embryo: in vitro and in vivo studies. Theriogenology 21, 84-102.

Norberg, H.S. (1973) Ultrastructural aspects of the preattached pig embryo: cleavage and early blastocyst stages. Z. Anat. Entw Gesch. 143, 95-114.

Oxenreider, S.L. \& Day, B.N. (1965) Transport and cleavage of ova in swine. J. Anim. Sci. 24, 413-417.

Paria, B.C., Sengupta, J. \& Manchanda, S.K. (1984) Role of embryonic oestrogen in rabbit blastocyst development and metabolism. J. Reprod. Fert. 70, 429-436.

Polge, C. (1982) Embryo transplantation and preservation. In Control of Pig Reproduction, pp. 277-291. Eds D. J. A. Cole \& G. R. Foxcroft. Butterworth
Scientific, London.

Polge, C. \& Frederick, C.L. (1968) Culture and storage of fertilized pig cggs. Proc. $6 \mathrm{th} \mathrm{lnt}$. Congr. Anim. Reprod. \& A.I., Paris 1, 211 , Abstr.

Polge, C., Adams, C.E. \& Baker, R.D. (1972) Development and survival of pig embryos in the rabbit oviduct. Proc. 7th Int. Congr. Anim. Reprod. \& A.I. Munich, pp. 513-517.

Pope, C.E. (1972) In vitro culture of preimplantation pig embryos. Ph.D. thesis, University of Missouri.

Pope, C.E. \& Day, B.N. (1977) Transfer of preimplantation pig embryos following in vilro culture for 24 or 48 hours. J. Anim. Sci. 44, 1036-1040.

Powell-Jones, C.H.J., Lester, J.B., Polge, C. \& Hartree, A.S. (1984) Pattern of medium proteins radiolabelled after culture of Day- 13 to -16 pig conceptus tissue with $\left[{ }^{3} \mathrm{H}\right]$ leucine and absence of chorionic gonadotrophin-like activity. $J$. Reprod. Fert. 71, 161-172.

Quinn, P. \& Wales, R.G. (1973) Growth and metabolism of preimplantation mouse embryos cultured in phosphate-buffered medium. J. Reprod. Fert. 35, 289-300.

Renard, J.P., du Mesnil du Buisson, F., Wintenberger-Torres, S. \& Menezo, Y. (1976) In vitro culture of cow embryos from Day 6 and Day 7. In Egg Transfer in Catle pp. 159-164. Ed. L. E. A. Rowson. Commission of the European Communities, Luxemburg.

Renard, J.P., Heyman, Y. \& Ozil, J.P. (1980) Importance of gestation losses after non-surgical transfer of cultured and non-cultured bovine blastocysts. Vet. Rec. 107, 152-153.

Rizzino, A. \& Sherman, M.I. (1979) Development and differentiation of mouse blastocysts in serum-free medium. Expl Cell Res. 121, 221-233.

Robl, J.M. (1979) Swine embryo developmem in vitro. M.Sc. thesis, Kansas State University.

Robl, J.M. \& Davis, D.L. (1981) Effects of serum on swine morulae and blastocysts in vitro. J. Anim. Sci. 52, 1450-1456.

Robl, J.M. \& First, N.L. (1985) Manipulation of pig gametes and embryos. J. Reprod. Fert., Suppl. 33, $101-114$.

Rundell, J.W. \& Vincent, C.K. (1968) In vitro culture of swine ova. J. Anim. Sci. 27, 1196, Abstr.

Samuel, C.A. (1971) The development of pig trophoblast in ectopic sites. J. Reprod. Fert. 27, 494-495.

Samuel, C.A. \& Perry, J.S. (1972) The ultrastructure of the pig trophoblast transplanted to an ectopic site in the uterine wall. J. Anat. 113, 139-149.

Schneider, H.J., Jr, Krug, J.L. \& Olds, D. (1975) Observations on recovery and culture of sow ova. J. Anim. Sci. 40, 187, Abstr.

Sengupta, J., Roy, S.K. \& Manchanda, S.K. (1982) Effect of an oestrogen synthesis inhibitor, 1,4,6-androstatriene-3,17-dione, on mouse embryo development in vitro. J. Reprod. Fert. 60, 457-460.

Shaffer, S.J. \& Wright, R.W., Jr (1978) Attachment and trophoblastic outgrowth of swine blastocysts in vitro. J. Anim. Sci. 46, 1712-1717.

Spindle, A.l. \& Pedersen, R.A. (1973) Hatching, attachment, and outgrowth of mouse blastocysts in vitro: fixed nitrogen requirements. $J$. exp. Zool. 186, $305-318$,

Stone, B.A., Quinn, P. \& Seamark, R.F. (1984) Energy 
and protein sources for development of pig embryos cultured beyond hatching in vitro. Anim. Reprod. Sci. $7,405-412$.

Tanquay, R.M. (1983) Genetic regulation during heat shock and function of heat shock proteins: a review. Can. J. Biochem. Cell Biol. 61, 387-394.

Tervit, H.R., Whittingham, D.G. \& Rowson, L.E.A. (1972) Successful culture in vitro of sheep and cattle ova. J. Reprod. Fert. 30, 492-497.

Warner, C.M. \& Tollefson, C.M. (1977) The effect of estradiol on RNA synthesis in preimplantation mouse embryos cultured in vitro. Biol. Reprod. 19, 332-337.

Warner, C.M. \& Tollefson, C.M. (1978) The effect of progesterone, estradiol and serum on RNA synthesis in preimplantation mouse embryos cultured in vitro. Biol. Reprod. 16, 627-632.

Whitten, W.K. (1971) Nutrient requirements for the culture of preimplantation embryos in vitro. Adv. Biosci. 6, 129-139.

Whitten, W.K. \& Biggers, J.D. (1968) Complete development in vitro of the preimplantation stages of the mouse in a simple chemically defined medium. $J$. Reprod. Fert. 17, 399-401.
Whittingham,D.G. (1972) The effect of copper on preimplantation development in the mouse. Biol. Reprod. 7, 140, Abstr.

Whittingham, D.G. \& Bavister, B.D. (1974) Development of hamster eggs fertilized in vivo or in vitro. J. Reprod. Fers. 38, 489-492.

Wilmut, I. \& Sales, D.I. (1981) Effect of an asynchronous environment on embryonic development in sheep. $J$. Reprod. Fert. 61, 179-184.

Wimsatt, W.A. (1975) Some comparative aspects of implantation. Biol. Reprod. 12, 1-40.

Wright, R.W., Jr (1977) Successful culture in vitro of swine embryos to the blastocyst stage. J. Anim. Sci. 44, 854-858.

Wright, R.W., Jr, Anderson, G.B., Cupps, P.T. \& Drost, M. (1976) Successful culture in virro of bovine embryos to the blastocyst stage. Biol. Reprod. 14, 157-162.

Wright, R.W., Jr \& Bondioli, K.R. (1981) Aspects of in vitro fertilization and embryo culture in domestic animals. J. Anim. Sci. 53, 702-729.

Wright, R.W., Jr, Watson, J.G. \& Chaykin, S. (1978) Factors influencing the in vitro hatching of mouse blastocysts. Anim. Reprod. Sci. 1, 181-188. 